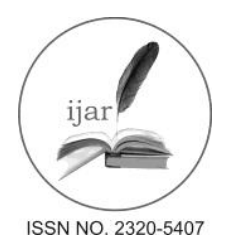

\author{
Journal homepage: http://www.journalijar.com

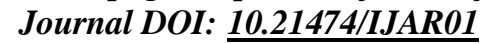

INTERNATIONAL JOURNAL

OF ADVANCED RESEARCH

RESEARCH ARTICLE

\title{
REASONING ABILITY AND ATTITUDE TOWARDS IN SCIENCE AMONG HIGHER SECONDARY STUDENTS.
}

\section{*C.DaisyNambikkai ${ }^{1}$ and Dr.A.Veliappan ${ }^{2}$.}

1. Research Scholar,Department of Education, ManonmaniamSundaranar University, Tirunelveli, Tamil Nadu.

2. Research Guide,Department of Education, ManonmaniamSundaranar University, Tirunelveli, Tamil Nadu.

\section{Manuscript Info}

Manuscript History:

Received: 18 April 2016

Final Accepted: 29 May 2016

Published Online: June 2016

Key words:

Reasoning ability, Attitude and Science.

*Corresponding Author

C.DaisyNambikkai.

\begin{abstract}
The present study aims to find out the relationship between reasoning ability and attitude towards science among the higher secondary students. Among the population, 724 sample sizes of higher secondary students were selected randomly from Puducherry region. Findings of the study were i) Significant difference is found among pure science, maths and computer science group higher secondary students in their reasoning ability in science on deductive reasoning and inductive reasoning. ii) Significant difference is found among pure science, maths and computer science group of higher secondary students in their attitude towards science. iii) Significant difference is found among rural, semi-urban and urban based residents' higher secondary students in their reasoning ability in science on analogical reasoning, classification as reasoning, deductive reasoning. iv) The higher secondary students from urban residents are found to be significantly better receiving attitude towards science. v) There exists significant positive relationship between attitude towards science and reasoning ability in science of higher secondary students.
\end{abstract}

Copy Right, IJAR, 2016. All rights reserved.

\section{Introduction:-}

Science education has become the backbone for the prosperity in each and every field of life (Divya K.K. and Usha P. 2013). Reasoning ability plays a significant role in one's life. It is an implicit act and involves problem solving behaviours using one's previous knowledge and experience. Attitudes have been defined as ideas with emotional context, important beliefs, prejudices, biases, predispositions, appreciations, and as status of readiness or set (Wan L Russell, 2006). A person who exhibits certain attitude towards something is reacting to their conception of that thing rather than to its actual state. Scientific attitude is absolutely necessary to dispel ignorance and backwardness; it will bring a balanced perspective to face the social evils and conflicts and could lead to a better world.

\section{Reasoning ability:-}

Reasoning is the cognitive process of looking for reasons, beliefs, conclusions, actions or feelings. In general, thinking, with the implication that the process is logical and coherent-more specifically, problem solving, whereby well informed hypotheses are tested systematically and solutions are logically deduced.

Reasoning is the process of higher order thinking where general principles are employed to draw relevant inferences. Skinner (1968) defined it as "The word used to describe the mental recognition of cause and effect relationships. It may be the prediction of an event from an observed cause or the inference of a cause from an observed event".

\section{Attitude towards Science:-}

Attitude towards science is an important aspect of a personality of someone who wants to be successful in the field of science. It requires rationality, inquisitiveness, and a need to investigate results. Attitude towards science can be 
defined as the feelings, beliefs and values held about an object that may be the endeavour of science that may be the impact of science and technology on society. (Gardner, 1975, Osborne, Simon\& Collins,2003).

\section{Review of related studies:-}

The review of related literature is to help the reader begin to appreciate something of the academic relationships within the subject area.

Srivastava (2013) conducted a study on "A study of relationship between environmental moral reasoning and scientific attitude among secondary students". This study reveals that exposure to science education from lower secondary to higher secondary tend to develop scientific attitude among students but not environmental moral reasoning ability.

Sekar (2013) conducted a study on "The scientific attitude and reasoning ability of biology and computer group students" The findings showed that i) there is no significant difference between the higher secondary boys and girls of biology group in scientific attitude. ii) there is no significant difference between the higher secondary boys and girls of computer group in scientific attitude. iii) there is significant difference between the higher secondary boys and girls of biology group in reasoning ability. iv) there is significant difference between the higher secondary boys and girls of computer group in reasoning ability. Scientific attitude remains more or less the same for boys and girls of biology group and computer group students. However, the reasoning ability for boys and girls of computer group and biology group students significantly differed.

\section{Plan and procedure:- \\ Reasoning ability Scale:-}

The investigator was used the reasoning ability scale prepared and validated by Anuradha Joshi and Bhuban Chandra Mahapatra (1994). It consists of 30 items with six dimensions namely analogy, classification, electic, deductive and inductive reasoning.

\section{Attitude towards Science Scale:}

The investigator administered the preliminary draft to the 176 higher secondary students and it is computed the item whole correlation. The coefficient of correlation between each item by all the scores and the sum of scores of all items for each scorer was calculated by pearson product moment formula. The items with a correlation value of And above are retained.

Analysis of data:- Analysis of data means studying the tabulated material in order to determine inherent facts or meanings (Koul, 1997).

Ho1:- There is no significant difference among pure science, maths and computer science course of higher secondary students with regard to their reasoning ability. 
Table 1:- Difference among pure science, maths and computer science group higher secondary students with regard to their reasoning ability in science.

\begin{tabular}{|c|c|c|c|c|c|c|}
\hline $\begin{array}{c}\text { Dimensions of } \\
\text { Reasoning ability }\end{array}$ & Categories & $\begin{array}{c}\text { Source of } \\
\text { variance }\end{array}$ & $\begin{array}{c}\text { Sum of } \\
\text { squares }\end{array}$ & $\overline{M S V}$ & F-value & Remarks \\
\hline Analogical reasoning & $\begin{array}{l}\text { Pure science } \\
\text { Maths } \\
\text { Computer science }\end{array}$ & $\begin{array}{l}\text { Between } \\
\text { Within }\end{array}$ & $\begin{array}{l}1.00 \\
1653.27\end{array}$ & $\begin{array}{l}0.50 \\
2.29\end{array}$ & 0.22 & NS \\
\hline $\begin{array}{l}\text { Classification as } \\
\text { reasoning }\end{array}$ & $\begin{array}{l}\text { Pure science } \\
\text { Maths } \\
\text { Computer science }\end{array}$ & $\begin{array}{l}\text { Between } \\
\text { Within }\end{array}$ & $\begin{array}{l}1.98 \\
1713.46 \\
\end{array}$ & $\begin{array}{l}0.99 \\
2.38 \\
\end{array}$ & 0.42 & NS \\
\hline Electic reasoning & $\begin{array}{l}\text { Pure science } \\
\text { Maths } \\
\text { Computer science }\end{array}$ & $\begin{array}{l}\text { Between } \\
\text { Within }\end{array}$ & $\begin{array}{l}6.85 \\
1450.83\end{array}$ & $\begin{array}{l}3.42 \\
2.01\end{array}$ & 1.70 & NS \\
\hline Deductive reasoning & $\begin{array}{l}\text { Pure science } \\
\text { Maths } \\
\text { Computer science }\end{array}$ & $\begin{array}{l}\text { Between } \\
\text { Within }\end{array}$ & $\begin{array}{l}11.39 \\
1607.73\end{array}$ & $\begin{array}{l}5.70 \\
2.23\end{array}$ & 2.55 & $S$ \\
\hline Inductive reasoning & $\begin{array}{l}\text { Pure science } \\
\text { Maths } \\
\text { Computer science }\end{array}$ & $\begin{array}{l}\text { Between } \\
\text { Within }\end{array}$ & $\begin{array}{l}26.20 \\
2052.88\end{array}$ & $\begin{array}{l}13.10 \\
2.85\end{array}$ & 4.60 & $S$ \\
\hline $\begin{array}{l}\text { Reasoning ability } \\
\text { (Total) }\end{array}$ & $\begin{array}{l}\text { Pure science } \\
\text { Maths } \\
\text { Computer science }\end{array}$ & $\begin{array}{l}\text { Between } \\
\text { Within } \\
\end{array}$ & $\begin{array}{l}104.16 \\
24725.82 \\
\end{array}$ & $\begin{array}{l}52.08 \\
34.29 \\
\end{array}$ & 1.52 & NS \\
\hline
\end{tabular}

S- Significant, NS- Not Significant df (2,722), the table value of 'F' is 2.99

From the above table shows that there is significant difference among pure science, mathematics and computer science group higher secondary students in their deductive and inductive reasoning. But there is no significant difference among analogical reasoning, classification as reasoning and reasoning ability in science.

Ho2:- There is no significant difference among pure science, maths and computer science group higher secondary students in their attitude towards science.

Table 2:- Difference among pure science, maths and computer science group higher secondary students in their attitude towards science

\begin{tabular}{|l|l|l|l|l|c|c|}
\hline $\begin{array}{l}\text { Attitude } \\
\text { towards } \\
\text { science }\end{array}$ & \begin{tabular}{l} 
Categories \\
\cline { 2 - 7 }
\end{tabular} & $\begin{array}{l}\text { Source of science } \\
\text { variance }\end{array}$ & $\begin{array}{l}\text { Sum of } \\
\text { squares }\end{array}$ & MSV & F-value & Remarks \\
\hline
\end{tabular}

S-Significant $\quad \operatorname{df}(2,722)$, the table value of ' $F$ ' is 2.99

From the above table shows that there is significant difference among pure science, mathematics and computer science group higher secondary students in their attitude towards science.

Ho3:- There is no significant difference among rural, semi urban and urban residents of higher secondary students in their reasoning ability in science 
Table 3:- Difference among rural, semi-urban and urban residents of higher secondary students in their reasoning ability in science.

\begin{tabular}{|c|c|c|c|c|c|c|}
\hline $\begin{array}{c}\text { Dimensions of Reasoning } \\
\text { ability in science }\end{array}$ & Categories & $\begin{array}{l}\text { Source of } \\
\text { variance }\end{array}$ & $\begin{array}{l}\text { Sum of } \\
\text { squares }\end{array}$ & MSV & F-value & Remarks \\
\hline Analogical reasoning & $\begin{array}{l}\text { Rural } \\
\text { Semi-urban } \\
\text { Urban }\end{array}$ & $\begin{array}{l}\text { Between } \\
\text { Within }\end{array}$ & $\begin{array}{l}47.22 \\
1607.05\end{array}$ & $\begin{array}{l}23.61 \\
2.23\end{array}$ & 10.59 & $S$ \\
\hline Classification as reasoning & $\begin{array}{l}\text { Rural } \\
\text { Semi-urban } \\
\text { Urban }\end{array}$ & $\begin{array}{l}\text { Between } \\
\text { Within }\end{array}$ & $\begin{array}{l}82.14 \\
1633.30\end{array}$ & $\begin{array}{l}41.07 \\
2.27\end{array}$ & 18.13 & $S$ \\
\hline Electic reasoning & $\begin{array}{l}\text { Rural } \\
\text { Semi-urban } \\
\text { Urban }\end{array}$ & $\begin{array}{l}\text { Between } \\
\text { Within }\end{array}$ & $\begin{array}{l}1.95 \\
1455.72\end{array}$ & $\begin{array}{l}0.98 \\
2.02\end{array}$ & 0.48 & NS \\
\hline Deductive reasoning & $\begin{array}{l}\text { Rural } \\
\text { Semi-urban } \\
\text { Urban }\end{array}$ & $\begin{array}{l}\text { Between } \\
\text { Within }\end{array}$ & $\begin{array}{l}19.42 \\
1599.70\end{array}$ & $\begin{array}{l}9.71 \\
2.22\end{array}$ & 4.38 & $S$ \\
\hline Inductive reasoning & $\begin{array}{l}\text { Rural } \\
\text { Semi-urban } \\
\text { Urban }\end{array}$ & $\begin{array}{l}\text { Between } \\
\text { Within }\end{array}$ & $\begin{array}{l}10.68 \\
2068.39\end{array}$ & $\begin{array}{l}5.34 \\
2.87\end{array}$ & 1.86 & NS \\
\hline Reasoning ability (Total) & $\begin{array}{l}\text { Rural } \\
\text { Semi-urban } \\
\text { Urban }\end{array}$ & $\begin{array}{l}\text { Between } \\
\text { Within }\end{array}$ & $\begin{array}{l}597.11 \\
24232.88 \\
\end{array}$ & $\begin{array}{l}298.55 \\
33.61 \\
\end{array}$ & 8.88 & $S$ \\
\hline
\end{tabular}

S-Significant NS- Not Significant df (2,722), the table value of ' $F$ ' is 2.99

From the above table shows that there is significant difference among rural, semi urban and urban residents of higher secondary students in their analogical reasoning, classification as reasoning, deductive reasoning and reasoning ability in science. But there is no significant difference among electic reasoning and inductive reasoning.

Ho4:- There is no significant difference among rural, semi urban and urban residents of higher secondary students with regard to attitude towards science.

Table 4:- Difference among rural, semi-urban and urban residents of higher secondary students in attitude towards science.

\begin{tabular}{|l|l|l|l|l|c|c|}
\hline $\begin{array}{l}\text { Attitude towards } \\
\text { Science }\end{array}$ & Categories & $\begin{array}{l}\text { Source of } \\
\text { variance }\end{array}$ & $\begin{array}{l}\text { Sum of } \\
\text { squares }\end{array}$ & MSV & F-value & Remarks \\
\cline { 2 - 7 } & $\begin{array}{l}\text { Rural } \\
\text { Semi-urban } \\
\text { Urban }\end{array}$ & Between & 7570.00 & 3785.00 & 8.50 & $\mathrm{~S}$ \\
\hline
\end{tabular}

S-Significant $\mathrm{df}(2,722)$, the table value of ' $\mathrm{F}$ ' is 2.99

From the above table it shows that, there is significant difference among rural, semi urban and urban residents of higher secondary students in their attitude towards science.

Ho5:- There is no significant relationship between attitude towards science and reasoning ability in science of higher secondary students

Table 5:- Relationship between attitude towards science and reasoning ability in science of higher secondary students.

\begin{tabular}{|l|c|c|c|c|}
\hline \multicolumn{1}{|c|}{$\begin{array}{c}\text { Attitude towards science Vs } \\
\text { Reasoning ability in science }\end{array}$} & Calculated value & N & Table value & Remarks \\
\hline Analogical reasoning & 0.036 & & & NS \\
Classification as reasoning & 0.164 & & & S \\
Electic reasoning & 0.027 & 724 & 0.0619 & NS \\
Deductive reasoning & 0.120 & & & S \\
\hline
\end{tabular}




\begin{tabular}{|l|c|c|c|c|}
\hline Inductive reasoning & 0.059 & & NS \\
& & & & \\
\hline Reasoning ability in science (Total) & 0.105 & & & $\mathrm{~S}$ \\
\hline
\end{tabular}

From the above table, it is inferred that the calculated 0.0619 value is greater than the table value at $5 \%$ level of significance. There is significant relationship is found between reasoning ability in science and attitude towards science of higher secondary students.

\section{Findings of the study:-}

1. Significant difference is found among pure science, maths and computer science group higher secondary students in their reasoning ability in science on deductive reasoning and inductive reasoning. The higher secondary students of pure science groups are found to be significantly better receiving reasoning ability in science on deductive reasoning and inductive reasoning. But there is no significant difference on analogical reasoning, classification as reasoning and electic reasoning.

2. Significant difference is found among pure science, maths and computer science groups higher secondary students in their attitude towards science. The higher secondary students from maths group are found to be significantly better receiving.

3. Significant difference is found among rural, semi-urban and urban based residents' of higher secondary students in their reasoning ability in science on analogical reasoning, classification as reasoning and deductive reasoning. The higher secondary students of semi-urban residents are found to be significantly better receiving reasoning ability in science on analogical reasoning, classification as reasoning and deductive reasoning. But there is no significant difference on electic reasoning and inductive reasoning.

4. Significant difference is found among rural, semi urban and urban residents of higher secondary students in their attitude towards science. The higher secondary students from urban residents are found to be significantly better receiving.

5. There exists significant positive relationship between reasoning ability in science and attitude towards science of higher secondary students.

\section{Interpretation of the study:-}

1. The higher secondary students of pure science groups are found to be significantly better receiving reasoning ability in science on deductive and inductive reasoning. This may be due to the fact that pure science students used to learn many facts about physics, chemistry and biology. So that they are capable of analysing and synthesising things. This finding is in harmony with the reviewed study of Sekar (2013).

2. The higher secondary students from maths group are found to be significantly better receiving attitude towards science. This may be due to the fact that maths group students learning style is through thinking and reflective level. While solving problems they have to think and use formula. But, for the pure science group students, contents are given in the form of textbook, they just used to learn the whole thing and reproduce the same in the examination.

3. The higher secondary students of semi urban residents are found to be significantly better receiving reasoning ability in science on analogical reasoning, classification as reasoning and deductive reasoning. This may be due to the fact that the semi urban students are living in the peaceful environment and all the facilities reachable to them easily. So they can learn many things from social network. After learning they find time to analyse, classify and deduct the activities that is whatever happened is perfect and what kind of change should be made. But rural students are growing in the hands of the parents by instructing everything to them. On the other hand urban students are fully engaged of some other extracurricular activities. So they don't find time to analyse the situations whatever happened in front of them even, parents are well-versed in selecting their goal, so that they are not ready to spend their time for classification as reasoning and deductive reasoning. This finding is in harmony with the reviewed studies of Gupta and Padhi (2015), Aseema and Gakhar (2004).

4. The higher secondary students from urban residents are found to be significantly better receiving attitude towards science. This may be due to the fact that urban students using technology. Semi urban students learning technology. Rural students listening about technology. Maintaining social relationship with the society also called attitude towards science. Urban students are extravert in nature, so that they ask their doubts to the teacher in the classroom itself in front of their friends. So that the students get their doubts clarified instantly 
and others in the classroom also receive confidence to raise doubts in the classroom. This finding is in harmony with the reviewed study of Vidhyageetha and Padma (2012).

5. There exists significant positive relationship between reasoning ability in science and attitude towards science of higher secondary students. The reason may be due to the fact that cognitive learning with the principles of behaviour modification given by behaviourists and says that cognitive functioning is more important in acquiring behaviour and reasoning. This finding is in harmony with the reviewed study of AraujoCandeias (2015),Srivastava (2013).

\section{Conclusion:-}

The present study clearly thing to see the structures of the reasoning ability in science and attitude towards science. It also empowers us to sort some important decisions for the educators to indoctrinate the reasoning ability and attitude towards science of the student community as it is needed for the development of scientific and technological world. On the basis of the results of this study and others it is acclaimed that the science teachers should be incorporate the reasoning ability during the teaching of science to progress the attitude of the students towards science learning, so that students may be able to work healthier in the field of science. One of the main tasks of the teacher is to improve the quality of student's thinking.

\section{References:-}

1. Bao, L. and Cai, T.(2009). Learning and Scientific Reasoning Science, New Delhi

2. BhaskaraRao.D. (2004).Scientific attitude, Discovery publishing house, New Delhi,

3. Coletta and Vincent, P. (2012). FCI normalized gain, scientific reasoning ability, thinking in physics, and gender effects Springer. (14)3.

4. Hamizul Hamid. (2012). A collaborative scientific reasoning model for teaching geography in the Malesian higher secondary schools.Journal of educational and instructional studies in the world. 2(3).

5. Jancirani,R and Devakrishnan,R.(2012). A study on scientific attitude of adolescence students in Namakkal district. International Educational E-Journal, 1(4), 2-8.

6. Jonathan Osborne. (2003). Attitudes towards science: a review of the literature and its implications. University of London. 25(9), 1049-1079.

7. Lampkin and Richard, H. (1938). Scientific Attitudes. Science Education, 22,353-357.

8. Lalitha,P.R. and Lakshminarayan,.U. (2002). The Study of Attitude of +2 students towards physics laboratory work. School science, 40 (2), 45-53. 